a portion of their labours are by no means sufficiently numerous. It is thus not women only, but men, the whole human race, that is stunted in its intellectual development at a time when its growth should be the most rapid, by the practical restriction to one half of the race only, of the means of acquiring the ability to help in this development.

We must next touch upon a subject of great delicacy; we refer to the instruction of women in medicine and surgery. There is an important distinction between this and all other departments of science. While it is competent to any one to teach chemistry, geology, or botany, and his success as a teacher will depend on his competency, the teachers and practisers of medicine and surgery form a guild, a professional trades' union, protected and licensed by the Government. It is in the nature of guilds and monopolies to be exclusive; and when we find that the medical profession is united almost as one man (with a few honourable exceptions) to resist the admission of women into its ranks, it is only what might with confidence have been predicted. The instinct of self-defence is a strong one; and if any evidence is required of the extent to which self-interest has entered into the causes of the opposition by the profession to the medical training of women, we need only refer to the "seven reasons against the admission of ladies to the profession" given in the British Medical Fournal for May 7 th. Into the abstract question of the utility of monopolies we need not enter; those who are excluded from their benefits are perfectly justified in using every legitimate effort to overthrow them, and in claiming the assistance of those who believe in the universal adaptation of the principles of free trade. Seldom have greater persistence and selfdenial been shown than by those few women who have laboured long and hard in this country, America, and France, in attempting to open to their sisters the doors of the medical profession. Careless of cruel misrepresentation, of public slander, of private persecution, they have held nobly on their course, and their services to mankind will one day be recognised.

Few have yet realised the enormous gain that will accrue to society from the scientific education of our women. If, as we are constantly being told, the "sphere of woman" is at home, what duty can be more clearly incumbent upon us than that of giving her the opportunity of acquiring a knowledge of the laws which ought to guide her in the rule of her house? Every woman on whom the management of a household devolves may profit by such knowledge. If the laws of health were better known, how much illness and sorrow might be averted! What insight would a knowledge of chemistry afford into the wholesomeness or unwholesomeness of different articles of food! What added zest would be given to a country walk with the children, or a month by the seaside, if the mother were able to teach the little ones intelligently to observe and revere the laws of Nature! Above all, what untold sufferings, what wasted lives, are the penalty we have paid for the prudish ignorance of the physiology of their bodily frame in which we have kept our daughters! These considerations have had far too little place with us at present.

We trust that a new era is dawning upon us ; may the higher education of women be pursued in the admirable spirit of the last report of the Edinburgh Ladies' Educational
Association :- "So far as we can see, cultivation does for women what it does for men-intensifies every moral attribute in proportion to the mental growth. Those who must go out into the world go out with a truer courage, founded upon a nobler estimate of work; those whose duties lie within the circle of home find them invested with a new and vivid significance from the higher elevation, and consequently larger views, of their own minds; and, finally, as 'woman is not undeveloped man,' we believe that womanhood can only be made more truly womanly, as manhood is made more truly manly, by the utmost use of the possibilities of high cultivation."

\section{NATURAL HISTORY COLLECTIONS}

$A$ LLOW me to give in my adhesion to the "platA form" established by the signers of the Memorial concerning the Natural History Collections, reprinted in your last number, and at the same time to request you to reprint a second Memorial on the same subject, presented in 1866 to the then Chancellor of the Exchequer. You will observe that this Memorial has likewise been signed by many distinguished men of science.

P. L. Sclater

\section{Copy of a Memorial presented to the Right Hon. the} Chuncellor of the Exchequer

SIR,-It having been stated that the scientific men of the Metropolis are, as a body, entirely opposed to the removal of the Natural History Collections from their present situation in the British Museum, we, the undersigned Fellows of the Royal, Linnean, Geological, and Zoological Societies of London, beg leave to offer to you the following expression of our opinion upon the subject.

We are of opinion that it is of fundamental importance to the progress of the Natural Sciences in this country, that the administration of the National Natural History Collections should be separated from that of the Library and Art Collections, and placed under one officer, who sl.ould be immediately responsib!e to one of the Queen's Minister s.

We regard the exact locality of the National Museum of Natural History as a question of comparatively minor importance, provided that it be conveniently accessible and within the Metropolitan district.

GEORGE BEnTHAM, F.R.S., F.L.S., F.Z.S.

WM. B. CARPENTER, M.D., F.R.S., F.L.S., F.G.S.

W. S. Dallas, F.L.S.

Charles DakWin, F.R.S., F.L.S., F.Z.S.

F. DUCANE GOdMan, F.L.S., F.Z.S.

J. H. GuRney, F.Z.S.

EDWard Hamilton, M.D., F.L.S., F.Z.S.

JOSEPH D. HOOKER, M.D., F.R.S., F.L.S., F.G.S.

Thos. H. Huxley, F.R.S., V.P.Z.S., F.L.S., F.G.S.

JOHN KIRK, F.L.S., C.M.Z.S.

LILFORD, F.L.S., F.Z.S.

AlFRED NEWTON, M.A., F.L.S., F.Z.S.

W. Kitchen PARKER, F.R.S., F.Z.S.

ANDREW RAMSAY, F.R.S., V.P.G.S.

Arthur Russeli, M.P., F.R.G.S., F.Z.S.

Osbert Salvin, M.A., F.L.S., F.Z.S.

P. L. SClater, F.R.S., F.L.S., F.Z.S.

G. SClater-BOOTh, M.P., F.Z.S.S.

S. James A. Salter, M.B., F.R.S., F.L.S., F.Z.S.

W. H. Simpson, M.A., F.Z.S.

J. EMERSON TENNENT, F.R.S., F.Z.S

THOMAS THOMSON, M.D., F.R.S., F.L.S.

H. B. TRISTKAM, M.A., F.L.S.

WALDEN, F.Z.S., F.L.S.

ALFRED R. WALLACE, F.R.G.S., F.Z.S. London, May 14, 1866 